UDC 681.52

DOI 10.36910/6775-2313-5352-2020-17-4

Hryniuk V.V., Vynnychuk A.G., Klochko N.B.

Ivano-Frankivsk National Technical University of Oil and Gas

\title{
DEVELOPMENT OF INFORMATION AND MEASUREMENT SYSTEM FOR AUTOMATIC REGULATION OF GREENHOUSE PREMISES MICROCLIMATE
}

The topical issue of increasing the efficiency of growing crops in greenhouses is considered in the work. The analysis of the microclimate main parameters in greenhouses is carried out. The urgency of developing an information and measuring system for automatic regulation of the greenhouses' microclimate is substantiated. Based on the analysis, it is established that the main information parameters of the greenhouses' microclimate are: temperature and soil moisture, temperature and humidity, lighting of the greenhouse. Automatic adjustment of these parameters is the basis of the developed information and measurement system. The operation principle of the information-measuring system is formulated and the choice of its main elements is made. The schematic diagram of the information-measuring system is developed and the peculiarities of its functioning are described. Basing on functional and electrical schematics the working model of information-measuring system for automatic regulation of greenhouse premises microclimate is constructed.

Key words: microclimate, regulation, information-measuring system, greenhouse.

Introduction. The growth and development of indoor plants is closely related to environmental conditions. In order to be able to do this, optimal microclimate conditions have to be provided. Under the microclimate we understand the conditions in a relatively isolated area (in this case - the room). These include parameters such as air and soil temperature, humidity and luminosity.

The microclimate cannot be constant. It varies depending on the season, day or night, as well as the state of the lower atmosphere in a given area at a certain time. Different crops require certain climate parameters. In addition, the greenhouse should protect plants from external stimuli, in particular: wind, frost, pests, etc. Modern greenhouses have certain characteristics which allows to reduce the probability of plant diseases and significantly increase yields.

Since most greenhouses are almost airtight, and natural light falls in insufficient quantities, which reduces the intensification rate of photosynthetic radiation plant uptake, a necessary condition for effective growth is the installation of special fluorescent phytolamps. Such lamps are the most optimal and economical option.

The spectrum of light and intensity are close to natural, due to this the microclimate of the greenhouse is not disturbed, and the processes of photomorphogenesis proceed faster [1]. Fluorescent phytolamps produce twice as much light energy per unit of electrical power than incandescent lamps and have a life of about 20,000 hours [2]. Such lighting saves energy resources, which will reduce the cost of crops grown.

Most modern greenhouses, which are built for growing early products, have a soil heating system. It is also advisable to control the temperature of the root layer with thermometers. Low substrate temperature (less than $8{ }^{\circ} \mathrm{C}$ ) blocks the supply of nitrogen and potassium to plants. At 10-15 ${ }^{\circ} \mathrm{C}$ in the area of the root system inhibits the flow of potassium, magnesium and phosphorus, on the other hand, high temperatures (more than $20^{\circ} \mathrm{C}$ ) at night increase the flow of sodium and calcium in the leaves, but reduce the level of phosphorus. Suppression of plant development at low temperatures, which is accompanied by symptoms of deficiency of the above nutrients, can be easily corrected by regulating the temperature of the heating circuit.

Indoor plants ripen much faster than in open ground. Only for the early harvest almost always you have to invest extra time and effort, because greenhouse crops are particularly in need of regular watering. Adjusting drip irrigation will simplify the care of plants, as well as reduce water consumption for irrigation. The chemical composition of the nutrient solution (calcium, magnesium, chlorine, iron, etc.) is also important [3].

Material and results of the study. Basing on the analysis, a functional diagram was developed (Fig. 1).

The element base for the construction of information and measuring system for climate control of greenhouses was chosen, namely: microprocessor platform (Arduino UNO), LCD display (LCD 
Nokia 5110), control buttons, sensors for measuring soil temperature (DS18B20), soil moisture 69), temperature and humidity (DHT-11) and illumination of the greenhouse (BH1750). The executive mechanism will be a four-channel relay module 5B (10 A) with galvanic isolation.

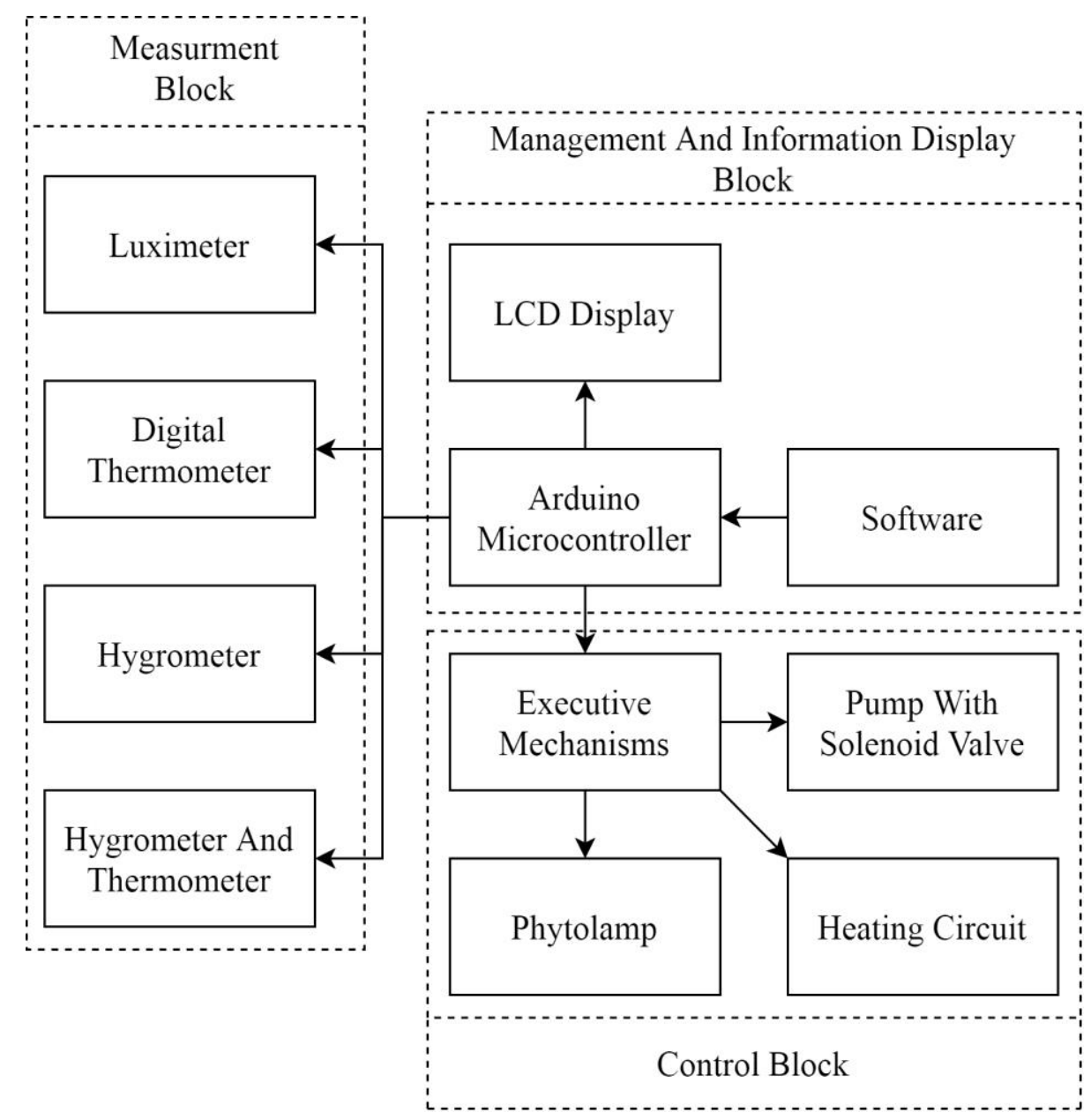

Fig.1. Functional diagram of the developed information and measurement system

Arduino UNO - microcontroller based on AVR controller, has the optimal ratio: pricefunctionality (capabilities) [5]. Technical characteristics: controller - ATmega328; operating voltage $5 \mathrm{~V}$; supply voltage (recommended) - 7-12 V; supply voltage (limit) - 6-20 V; digital inputs/outputs 14; analog inputs - 6; maximum current of one pin (contact) - $40 \mathrm{~mA}$; maximum output current - 3.3V $50 \mathrm{~mA}$; alash memory - $32 \mathrm{~KB}$ (ATmega328), $0.5 \mathrm{~KB}$ used by bootloader; SRAM - $2 \mathrm{~KB}$; EEPROM $1 \mathrm{~KB}$; clock frequency - $16 \mathrm{MHz}$.

LCD Nokia 5110 - for displaying information. Controlled by the serial SPI interface, displays the simplest graphics [6]. Technical characteristics: dimension - 84x84 pixels; the size of the working field - 31x19 mm; illumination - light blue; LCD controller - PCD8544; supply voltage - 2.7-3.3 V; display current consumption - less than $5 \mathrm{~mA}$; backlight current consumption - up to $10 \mathrm{~mA}$; the size of the module - $43 \times 45 \mathrm{~mm}$; operating temperature - from 0 to $+50{ }^{\circ} \mathrm{C}$.

DS18B20 - temperature sensor [7]. Made in a waterproof case. Technical characteristics: supply voltage - from 3 to $5,5 \mathrm{~V}$; temperature measurement range - from -55 to $+125{ }^{\circ} \mathrm{C}$; measurement error (in the range $-10 \ldots+85 \mathrm{C}$ ) $-0.5^{\circ} \mathrm{C}$; measurement time (does not exceed) $-750 \mathrm{~ms}$; interface -1 -Wire.

Y1-69 - soil moisture sensor. Made in the form of a fork, which has to be stuck in the ground for measurements [8]. Technical characteristics: the maximum depth of immersion in soil $-40 \mathrm{~mm}$; maximum current consumption - $50 \mathrm{~mA}$; supply voltage - 3.3-5 V; the size of the block of the comparator $-14 \times 31$; the size of the sensor is $20 \times 66 \mathrm{~mm}$.

DHT-11- humidity and air temperature sensor [9]. It consists of a sensitive capacitive element, an NTC thermistor, and an 8-bit chip that converts an analog signal from sensors to digital. Technical characteristics: supply voltage - $3 . .5 \mathrm{~V}$; output signal - digital; maximum current consumption - 2.5 $\mathrm{mA}$ during conversion (when requesting data); sensitive element - polymer capacitor, NTC thermistor; 
humidity measurement range $-20 \ldots 90 \%$, error $\pm 5 \%$; temperature measurement range $-0{ }^{\circ} \mathrm{C} \ldots+50$ ${ }^{\circ} \mathrm{C}$, error $\pm 1{ }^{\circ} \mathrm{C}$; minimum delay in measurement $-1 \mathrm{~s}$.

BH1750 - light sensor [10]. The measurement is performed using a photodiode. Technical characteristics: chip - BH1750FVI ROHM; filtering of light noise - 50/60 Hz; operating supply voltage - 3.3-5V; current consumption - $120 \mu \mathrm{A}$; current consumption in sleep mode - $0.01 \mu \mathrm{A}$; sensitivity - 65536 gradations; accuracy in the mode of high resolution - $1 \mathrm{Lk}$; accuracy in the mode of low resolution - $4 \mathrm{Lk}$; measurement period in high resolution mode - $120 \mathrm{~ms}$; measurement period in low resolution mode - $16 \mathrm{~ms}$; data bus - I2C interface.

The electrical schematic diagram of the developed information and measurement system is presented in Figure 2.

The software (algorithm of work) is written in the Arduino IDE programming environment, using the $\mathrm{C}$ programming language [4].

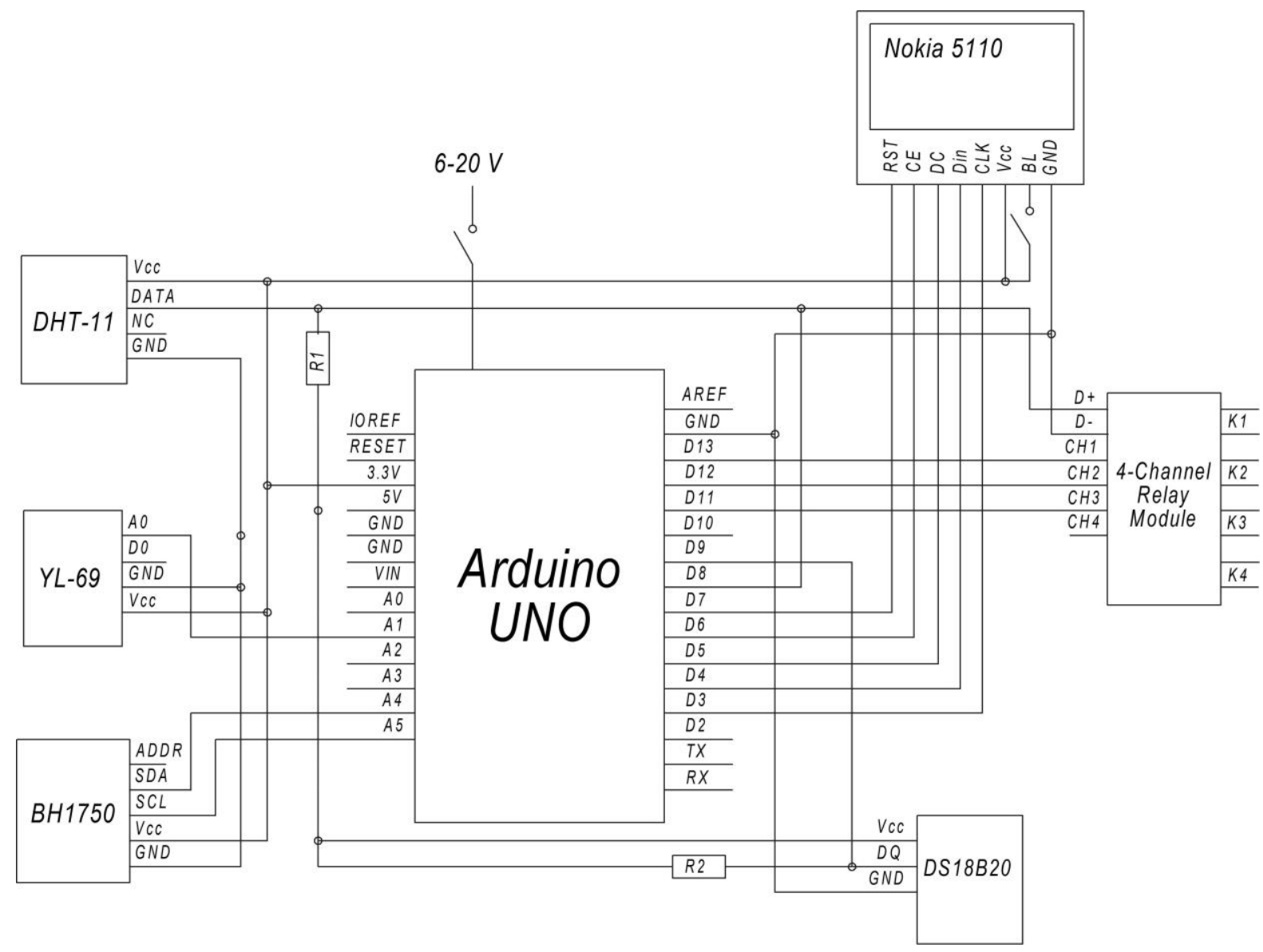

Fig.2. Electrical schematic diagram of developed information and measurement system

The principle of operation of the developed system is following: microclimate parameters (minimum and maximum values) and the interval for reading data from the sensors are set. If the measured parameter exceeds the specified limits, the heating circuit, pump with solenoid valve or phytolamps are switched on or off via the executive mechanism (relay). The display is used to display the current data received from the sensors. The block diagram of the algorithm is presented in Figure 3. 


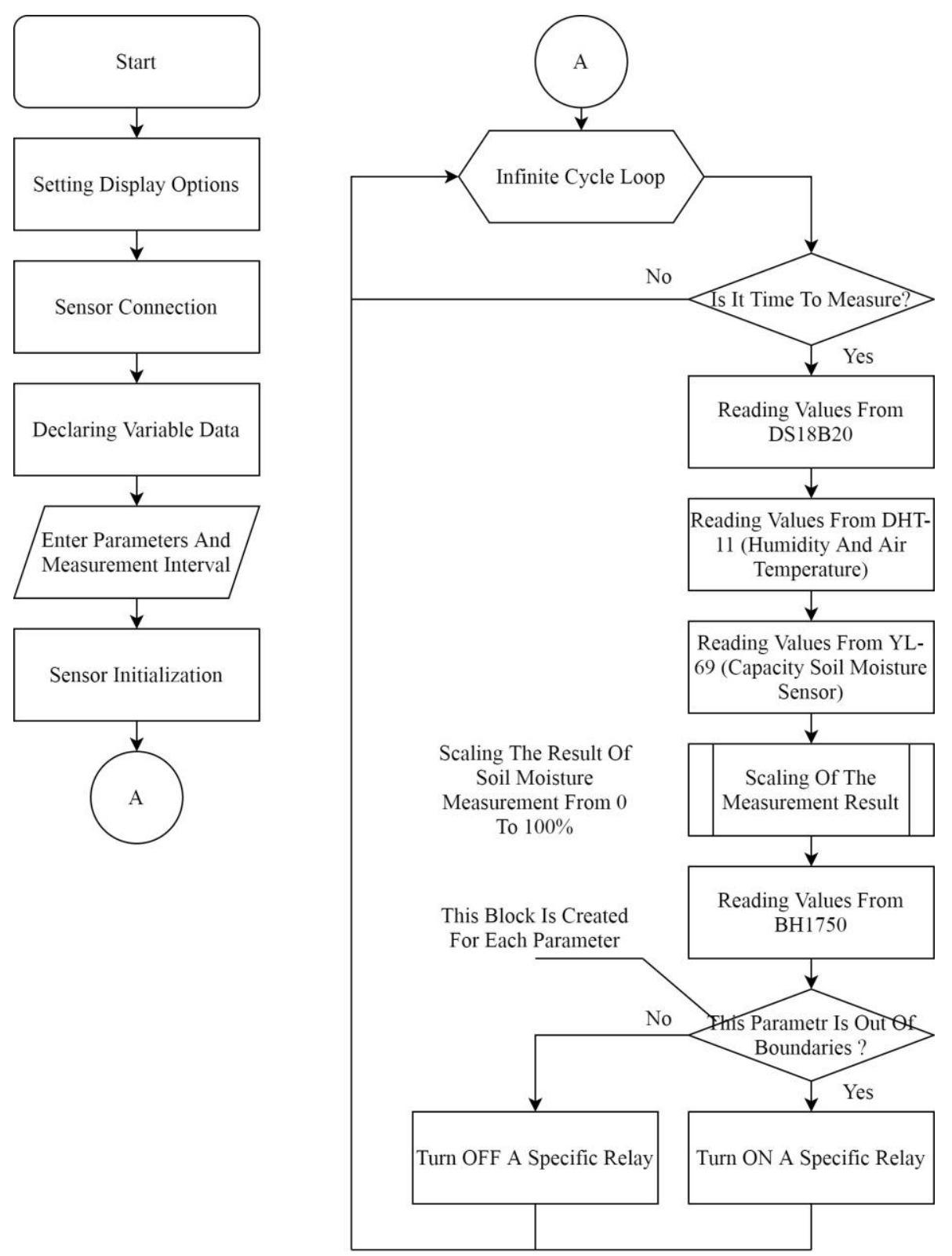

Fig.3. Block diagram of the algorithm of the developed system

Conclusions. Today, in many sectors of the economy, there comes a time when it is necessary to increase productivity and reduce costs. At first glance, this seems to be a mutually exclusive concept, however, in the developed system, we tried to implement it by automating key processes related to regulation. This issue is especially relevant for owners of small greenhouses.

\section{References}

1. Makrushin M.M., Makrushina E.M., Peterson N.V., Melnikov M.M. Plant Physiology: a textbook / edited by prof. M.M. Makrushina. Vinnytsia: Nova Kniga, 2006. 416 p.

2. Pavliuk A.V. Analysis of modern lighting systems in protective soil. Scientific student readings - 2016: a collection of materials of the scientific-practical conference of students. Zhytomyr, 2016. P.150-157.

3. Bekkalieva M.A., Nurmukhanova A.A., Kazhenov R.A., Gubasheva B.E. Influence of irrigation water quality on growth and development of tomatoes. A young scientist. 2019. № 8 (28). Pp. 88-91.

4. We study Arduino: tools and methods of technical magic: Translated from English - SPb.: BHV-Peterburg, 2015. 336 p. 
5. Baran V.S., Vlasiuk G.G., Onikienko Y.O., Smolenskaia O.I. Fundamentals of microprocessor technology: laboratory workshop: textbook for students. specialty 171 "Electronics". Kyiv: KPI named after Igor Sikorsky, 2019. 140 p.

6. Nokia 5110 LCD display. Access mode: https://radioprog.ru/shop/merch/48

7. DS18B20 - temperature sensor with 1-Wire interface. Description. Access mode: http://mypractic.ru/ds18b20-datchik-temperatury-s-interfejsom-1-wire-opisanie-na-russkomyazyke.html

8. Soil moisture sensor. Access mode: https://3d-diy.ru/wiki/arduino-datchiki/datchikvlazhnosti-pochvy-arduino/

9. Temperature and humidity sensors DHT11 and DHT22 and Arduino. Access mode: http://arduino-diy.com/arduino-datchiki-temperatury-i-vlazhnosti-DHT11-i-DHT22

10. BH1750 - Digital light sensor / luxmeter (module GY-302). Access mode: https://micropi.ru/bh1750-gy-302-датчик-освещенности.

\section{Список використаних джерел}

1. Макрушин М. М., Макрушина Є. М., Петерсон Н. В., Мельников М. М. Фізіологія рослин: підручник / за редакцією проф. М. М. Макрушина. Вінниця: Нова Книга, 2006. 416 с.

2. Павлюк А.В. Аналіз сучасних систем освітлення в умовах захисного грунту. Наукові студентські читання - 2016: збірник матеріалів науково-практичної конференції студентів. Житомир, 2016. С.150-157.

3. Беккалиева М. А. Нурмуханова А. А., Каженов Р. А., Губашева Б. Е. Влияние качества поливной воды на рост и развитие томатов. Юный ученый. 2019. № 8 (28). С. 88-91.

4. Изучаем Arduino: инструменты и методы технического волшебства: Пер. с англ. СПб.: БХВ-Петербург, 2015. 336 с.

5. Баран В.С., Власюк Г.Г., Оникієнко Ю.О., Смоленська О.І. Основи мікропроцесорної техніки: лабораторний практикум: навч. посіб. для студ. спеціальності 171 «Електроніка». Київ: КПІ ім. Ігоря Сікорського, 2019. 140 с.

6. LCD дисплей Nokia 5110. Режим доступу: https://radioprog.ru/shop/merch/48

7. DS18B20 - датчик температуры с интерфейсом 1-Wire. Описание. Режим доступу: http://mypractic.ru/ds18b20-datchik-temperatury-s-interfejsom-1-wire-opisanie-na-russkomyazyke.html

8. Датчик влажности почвы. Режим доступу: https://3d-diy.ru/wiki/arduino-datchiki/datchikvlazhnosti-pochvy-arduino/

9. Датчики температуры и влажности DHT11 и DHT22 и Arduino. Режим доступу: http://arduino-diy.com/arduino-datchiki-temperatury-i-vlazhnosti-DHT11-i-DHT22

10. ВН1750 - Цифровой датчик освещенности/люксметр (модуль GY-302). Режим доступу: https://micro-pi.ru/bh1750-gy-302-датчик-освещенности.

Гринюк В.В., Винничук А.Г., Клочко Н.Б.

Ивано-Франковский национальный технический университет нефти и газа

\section{РАЗРАБОТКА ИНФОРМАЦИОННО-ИЗМЕРИТЕЛЬНОЙ СИСТЕМЫ АВТОМАТИЧЕСКОГО РЕГУЛИРОВАНИЯ МИКРОКЛИМАТА ТЕПЛИЧНЫХ ПОМЕЩЕНИЙ}

В работе рассмотрен актуальный вопрос повышения эффективности вырашивания сельскохозяйственных культур в тепличных помещения. Осуществлен анализ основных параметров микроклимата в тепличных помещениях. Обоснована актуальность разработки информационно-измерительной системы автоматического регулирования микроклимата тепличных помещений. На основе проведенного анализа установлено, что основными информачионными параметрами микроклимата тепличных помещений являются: температура и влажность почвы, температура и влажность воздуха, освещееность тепличного помещения. Автоматическое регулирование этих параметров положено в основу разработанной информационно-измерительной системы. Сформулирован принцип работы информационно-измерительной системы и осуществлен выбор основных ее элементов. Разработана принципиальная схема информационно-измерительной системь и описань особенности ее функиионирования. На основе функииональной и электрической 
принципиальной схем построено рабочий макет информационно-измерительной системы автоматического регулирования микроклимата тепличных помещений.

Ключевые слова: микроклимат, регулирования, информационно-измерительная система, тепличное помещение.

Гринюк В. В., Винничук А.Г., Клочко Н.Б.

Івано-Франківський національний технічний університет нафти і газу

\section{РОЗРОБЛЕННЯ ІНФОРМАЦЙНО-ВИМІРЮВАЛЬНОЇ СИСТЕМИ АВТОМАТИЧНОГО} РЕГУЛЮВАННЯ МІКРОКЛІМАТУ ТЕПЛИЧНИХ ПРИМІЩЕНЬ

В роботі розглянуто актуальне питання підвищення ефективності вирощування сільськогосподарських культур в тепличних приміщеннях. Здійснено аналіз основних параметрів мікроклімату в тепличних приміщеннях. Обгрунтовано актуальність розроблення інформаційно-вимірювальної системи автоматичного регулювання мікроклімату тепличних приміщень. На основі проведеного аналізу встановлено, що основними інформаційними параметрами мікроклімату тепличних приміщень є: температура та вологість трунту, температура та вологість повітря, освітленість тепличного приміщення. Автоматичне регулювання иих параметрів покладено в основу розробленої інформаційно-вимірювальної системи. Сформульовано принци роботи інформаційно-вимірювальної системи та здійснено вибір основних ї̈ елементів. Розроблено принципову схему інформаційно-вимірювальної системи та описано особливості ї̈ функиіонування. На основі функиіональної та електричної принципової схем побудовано робочий макет інформаційно-вимірювальної системи автоматичного регулювання мікроклімату тепличних приміщень.

Ключові слова: мікроклімат, регулювання, інформачійно-вимірювальна система, тепличне приміщення. 